\title{
Prevention Children Sexual Abuse in Preschool with Picture Story Book
}

\author{
Dyah Rahmawatie Ratna Budi Utami ${ }^{1 *}$, Erika Dewi Noorratri ${ }^{2}$ \\ ${ }^{1,2}$ Aisyiyah University Surakarta \\ *Email: dyahrahmawatie@gmail.com \\ https://doi.org/10.30787/gaster.v19i1.669
}

\begin{tabular}{ll} 
ARTICLE INFO & \multicolumn{1}{c}{ ABSTRACT } \\
\hline Keywords: Story book with & Background: Children sexual abuse (CSA) is a form of concern \\
picture; prevention; KSA & for parents and society, given the phenomenon that occurs is like \\
an iceberg with an increasing prevalence every year. Parents \\
play an important role in KSA prevention education, but the \\
majority are confused about how to explain it. The picture \\
book is expected to be a medium for educating parents to their \\
children regarding the prevention of CSA in preschool children. \\
Purpose: to produce a picture book as an effort to prevent CSA. \\
Methods: This study used a research and development design. \\
The development of this pictorial story book uses information \\
from parents and teachers for initial data collection, while for \\
product validation a team of experts consisting of material \\
experts, media experts and linguists are used for product \\
validation. Meanwhile, for the public test was 34 parents. The \\
instruments used were interview guides and questionnaires. The \\
data were analyzed qualitatively and quantitatively. Result: \\
There is creation of ABIJAGARI a story book in the prevention \\
of child sexual abuse that consist of 17 pages. Conclusion \\
The picture story book entitled ABIJAGARI can be used as an \\
alternative media in education on prevention of CSA
\end{tabular}

\section{PRELIMINARY}

Child sexual abuse (CSA) is the coercion, threat or reliance on a child in sexual activity. These sexual activities include contact and non contact such as seeing, groping, penetration (pressure), sexual abuse and rape (Tunc et al., 2018). The impact of CSA on children can cause physical and psychological symptoms from the victim. Physical impacts can be in the form of injuries to the genitals or rectum, 
while psychological impacts include mental trauma, fear, shame and depression (Russell, et al, 2020)

The Indonesian Child Protection Commission (KPAI) explained that from January to October 2014, 784 cases of child sexual violence were recorded. This means that an average of 129 children are victims of sexual violence each month, and $20 \%$ of children are victims of pornography. Meanwhile, according to the National Police, there were 697 cases of sexual violence against children that occurred in half of 2014 (Setyawan, 2014). The Witness and Victim Protection Agency (LPSK) noted an increase in requests for protection of sexual violence against children. Since 2016-2019 there has been an increase in numbers based on LPSK applicants (Alfons, 2019). The public opinion that sex is taboo to teach children, especially in early childhood. Ironically, many cases of children under 7 years are easy targets for perpetrators of sexual crimes (Yamira, 2014)

Article 15 point $f$ of Law No. 35 of 2014 states that every child has the right to protection against sexual crimes (Kemenkumham RI, 2014). Therefore, from an early age, parents or teachers teach children about the prevention of sexual violence in accordance with the child's development.
Sexual violence prevention education can be provided as early as possible. Preschoolers have adjusted large amounts of information in their short life span. Inculcating the right information can be useful in the principles and outlook on life of children at a later stage of development (Perry et al., 2014)

Various ways can be done as a form of efforts to prevent sexual violence against children such as games, learning, puppet shows, drama or discussion groups (Müller, et al, 2014). Several studies state that comprehensive and multidimensional sexual violence prevention programs are the most effective means of preventing sexual violence against children (Bustamante et al., 2019)

This study aims to produce a picture book in an effort to prevent sexual violence in preschool children. This picture book is expected to be an alternative solution to the increasing cases of sexual violence against children, the negative impact of KSA and the confusion of parents to explain how to teach prevention of sexual violence to children.

\section{MATERIALS AND METHODS}

This research uses research and development methods, also known as Research and Development. This research went through three stages, namely the stage of 
preparation, implementation and termination.

The preparatory stage, the researcher searches the literature and related phenomena, makes a permit, then the researcher conducts a preliminary study. The implementation stage, the researcher prepares and collects data (material, basic competencies to be achieved, parental characteristics and the difficulties of parents teaching CSA prevention), product format development (picture book), product validation, product revision, product testing, revision the final product. Termination stage, the researcher performs data processing, creates reports and disseminates the results.

Inclusion criteria for the sample of this study were fathers or mothers who have children aged 4-6 years old, can read and follow the course of the study. The exclusion criteria for this study were not completing the research procedure until the end.

\section{RESULTS AND DISCUSSION}

This study aims to produce a picture book as an effort to prevent sexual violence in pre-school children. Researchers developed this picture story book through several stages starting from needs analysis, making pictorial story books, validating and testing the product.

1. Needs Analysis Results

The needs analysis was carried out by conducting interviews with teachers and parents of pre-school age students who attend TK 'Aisyiyah 3 Ngringo, TK Pembina and TK Indriyasana. The process of extracting information with the research teacher was carried out in the form of a focus group discussion (FGD) on July 21, 2020. Meanwhile, we did extracting information from parents through gradual interviews. The items of information that we collect include: materials, media, constraints, education on prevention of sexual violence that has been given or experienced directly by mothers and teachers as well as suggestions for books to be made.

The first data collection process was using FGD with teachers from 3 schools namely TK 'Aisyiyah 3 Ngringo, TK Indriyasana and TK Pembina Jaten. A summary of the results of the FGD conducted with kindergarten teachers and parents can be seen in the following table 
Table 1. Results of the FGD with teachers and parents

\begin{tabular}{cll}
\hline No. & List of questions & Summary of Results \\
\hline $\mathbf{1}$ & $\begin{array}{l}\text { Situation teached } \\
\text { sex education to pre- } \\
\text { school age children }\end{array}$ & $\begin{array}{l}\text { The teacher teaches sex education to children for the prevention } \\
\text { of sexual violence in children in class or there are incidents / } \\
\text { phenomena of male and female interactions, such as boys joining } \\
\text { toileting with girls, boys hugging girls }\end{array}$
\end{tabular}

2 The material taught Teaches about politeness, aspects of character: boundaries of to children behavior between men and women, explanation of personal organs such as those in the kindegarten children's curriculum material and explains material according to existing phenomena, for example: when there are girls going to the bathroom and boys men come. Besides that, he also pursues 4 areas that should not be touched by other people

3 Media and methods Pictures of boys and girls in kindergarten about everyday stories. used Leaflets and cards yes no. In addition, I have also taught about touch, whether or not to use songs. The method chosen was in the form of stories and group or private discussions

4 Constraints and suggestions for constraints

there is no media regarding the prevention of CSA, there is a feeling of discomfort / embarrassment when explaining especially the discussion of penis / vagina, the lack of synchronization of the roles of parents and teachers regarding the prevention of CSA,

5 Suggestions regarding content and media models (picture book)

the material presented: touch is allowed and not, actions that need to be taken if touch is not allowed, between the story and the dominant image of the image, for school, it can use a minimum size of A3 and what parents and children do can be A4 size. Between the story and the picture there are more pictures and also the use of interesting colors.

Education on the prevention of sexual abuse is a quite sensitive theme in terms of Eastern cultural values that apply in Javanese society in particular or the perception of taboo makes conversations about preventing sexual violence less than optimal. This is in accordance with research that kindergarten teachers sometimes feel uncomfortable and confused when explaining about the prevention of sexual violence, especially personal limbs (Utami,et al, 2016). Teachers and parents expressed the need for an attractive medium for teaching the prevention of CSA. Media serves as a tool to achieve learning objectives, media 
is also used as a tool to attract students 'attention, and to keep students' attention during the lesson (Dasna, et al, 2015)

Teacher and parens have important part to teach prevention CSA (Justicia, 2016). The role of parents or families in preventing sexual violence against children is very important because the parents are the closest people to the child and the role of parents is very important in helping children to be ready to go to the gates of their lives, by maximizing their role as a family will be a strong fortress in anticipating there are bad things that can happen to the environment of family members (Ligina, et al, 2018). Apart from parents and families in preventing child sexual violence, the role of teachers is very important. School children are in a school environment where sexual violence may occur. The teacher provides education related to the prevention of sexual violence against children

The results of the teacher's FGD explained that there was no specific media used by the teacher to teach education on prevention of sexual violence. The same thing was also stated by parents that teaching the prevention of sexual violence is still lacking in confidence because of the perception of taboo and does not have special media that is attractive and in accordance with the theme of preventing sexual violence against children.

Pre-school age children are included in the concrete operational stage where children begin to think rationally and logically. Children can solve problems based on their experiences (Perry et al., 2014). Efforts to prevent sexual violence can be done through games, learning, puppet shows, dramas or discussion groups. The picture story book is an attractive medium for children because it consists of pictures and writing (Tutty et al., 2019).

2. Initial Product Description (Picture Story Book)

The following is a description of the arrangement of a picture story book:

a. Guide to using books

Guidelines for using picture story books will make it easier for users to know and understand the purpose of the storybook contents

b. Concept

Based on the needs analysis that has been conducted with teachers and parents, the concept of this book is a pictorial story about preventing sexual violence. The story in this 
book describes a child who gets unsafe touches from someone. With the existence of this story book, it can facilitate teachers or parents in providing knowledge to children about the permissible and don't touches and what to do if you get a touch not allowed.

c. Figure

The main character in this pictorial story is a boy named Adi. Apart from Adi there is also Adi's mother, a man with evil intentions and a father. Adi's character is brave, cheerful, and likes to play. Mother is a figure who is calm, wise and child protection. Father has a child protective character.

d. Book format and size

This book is A4 size $(21 \times 29.7$ $\mathrm{cm}$ ) and has 17 pages including front and back covers. This picture book has a conclusion which is the result of input from the results of expert validation and serves as reinforcement of information to mothers or teachers regarding items that must be conveyed to children.

e. Book content and theme

The contents of this book are information about how to protect yourself from crimes against sexual violence. Providing information about unsafe touching types in the form of Adi's story and also how to refuse and report the time when he received such unsafe touch. The pictures and contents of this picture story book are closely related activities in a child's daily life. The pictures and colors chosen are in accordance with the character of the child who is light and cheerful. Stories, names, characters and simple conversations are shown to teachers, parents and children. Adi's character in this book's story has a brave and cheerful character.

f. Book title

The title of this picture story book is "I Can Take Care of Myself". Below is a look at the title and cover page of this book.

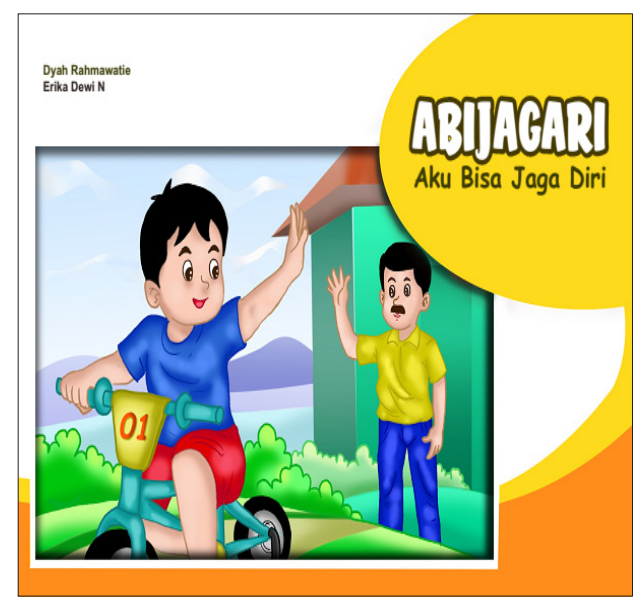

Picture1: cover story book 
g. Image design

The images made in this story book use images that are processed using a computer application, the existing images give a simple, modern, cheerful and clear impression to facilitate children's understanding. The image content on each sheet is more dominant than the writing.

h. Engineering workmanship

The work of this pictorial story book begins with drafting the contents of the book (script) then drafting the image which is then processed using a computer application.

i. Color

The colors chosen are bright colors. Researchers chose bright colors to attract children's attention and match the pre-school age children's personality.

j. Typography

The typography style used in the development of this picture story book is arial for the content of the story. The typography used has writing characters that are suitable and attractive to children so that it invites children's reading interest, namely Comic Sans MS. k. Print technique

The type of paper used to print this book is art paper 260. For the binding technique, ring binding technique is used. The contents of the book use a one-width print instead of back and forth.

This illustrated story book makes children learn about the values of preventing sexual violence in children and unwittingly gradually adopts the values of preventing sexual violence against children in everyday life for children which include recognition of touch and don'ts, how to reject and report. to trusted adults.

A picture story book is a graphic learning medium consisting of pictures, symbols, writing, expressions, and messages. The material that will be given to children will be illustrated in pictures and assisted by short stories so that children are interested and better understand the concept through pictures and writing (Oktarina and Liyanovitasari, 2019). The storyline and image illustrations are mutually supportive elements in a story and cannot be separated, so that picture story books besides presenting the storyline are also 
given an overview of the story through illustrations that are visible to the child (Indrayani et al, 2020).

Sexual abuse, as one of the most destructive types of misconduct, can have serious lifelong consequences (Navaei, et al, 2018). Sexual violence against children, both girls and boys, should not be ignored. Sexual violence against children is something that violates morals and laws, and hurts a person both physically and psychologically. Sexual violence against children can be done in the form of rape, sexual abuse, sodomy and incest (Noviana, 2015).

Cases of sexual abuse against children will have an impact. It is necessary to require efforts to prevent further victims. One of the efforts that can be done is by providing knowledge or sex education from an early age to children. Understanding sex in preschoolers is expected so that children can get the right information and knowledge about sex, because many media teach about sex. This is an effort to prevent sexual violence against children (Sulistyowati, et al, 2018). Parents can do things such as involving children in planning family activities, making decisions, and solving family problems, increasing knowledge and understanding of reproductive health and the digital world, taking time to do activities together, accompanying children when they experience difficulties at home. and in schools as an effort to prevent sexual violence against children (Haryana, Djaja and Maznah, 2017)

The delivery of prevention of sexual violence in children is carried out gradually, carefully and according to the child's development. The media content is adapted to the sexual violence prevention material that parents or teachers can give to children, which includes the introduction of 4 areas of the body that cannot be touched by other people, for example refusing and reporting if you get unsafe touch (Bustamante et al., 2019). Material for preventing sexual violence in pre-school age children includes teaching safe and unsafe touch, introducing limbs, and taking action if you get unsafe touch using media that is attractive to children (Utami and Susilowati, 2018).

3. Expert Validation Results (Expert)

Expert validation related to this picture story book is carried out by means of content validity which includes design, writing, colors, images and 
content. The experts that the author chose include someone who is involved in the field of early childhood education, namely kindergarten supervisors, design experts (lecturer in Communication and Visual Design) and activists from nongovernmental organizations (NGOs). The NGO chosen was the Big Brother NGO, which often gave promotions or handled cases of sexual violence against children in the Surakarta residency area. In general, the three expert validators said that the picture book that had been compiled could be used as an educational medium with several revisions.

Based on the validation results of 3 experts, all of them said that this picture story book was informative, simple, and clear in conveying the content. The pictures provide an explanation of the content of the story. The contents of this illustrated story book are good and easy for children to understand in the prevention of sexual violence against children, including safe and unsafe touching, how to refuse and report. This picture story book is more dominant with pictures than writing. The three experts concluded that this story book is suitable for use with improvements as suggested.

4. Test Results

The results of product trials on 36 respondents represented by mothers had an average value of 42.01. The details based on the categories can be seen in the following table:

Table. 1.2 Distribution of Mother's Perception Frequency of the Picture Book of Prevention of Sexual Violence in Children.

\begin{tabular}{lccc}
\hline Category & Score & Amount & Percentage (\%) \\
\hline Very good & $37-48$ & 32 & 88.9 \\
Good & $25-36$ & 4 & 11.1 \\
Pretty good & $13-24$ & 0 & 0 \\
Not good & $11-12$ & 0 & 0 \\
\hline Total & & 36 & 100 \\
\hline
\end{tabular}

Books can provide information, as well as entertain. Books are also a place for collecting one's past, as well as an agent for personal development and social change, as well as a reflection of culture Picture books provide an attractive color 
that can attract someone to want to read and see the book.

Story books about the introduction of early sex, besides being able to help children stimulate imagination, they can also help children get pleasure. The book includes stories and pictures that are interesting, apart from being interesting and good, and tend to be realistic, and there are funny things that can stimulate children to be happy (Indrayani,et $a l$, 2020). If children are happy with what they read, they will increase their comprehension and make it easier to remember and understand what they read. It can be seen that children's knowledge increases when they finish reading the picture story book.

\section{CONCLUSIONS AND SUGGESTIONS}

The results of the teacher's Focus Group Discussion explained that there was no specific media used by the teacher to teach education on prevention of sexual violence. The mother's perception of this Picture Book of Sexual Violence in Children Prevention is very good. Suggestions for teachers and parents to be creative in media selection and how to teach sexual violence prevention education.

\section{BIBLIOGRAPHY}

Alfons, M. (2019) 'LPSK: Kasus Kekerasan Seksual pada Anak Meningkat Tiap Tahun', detikcom. Available at: https:// news.detik.com/berita/d-4637744/ lpsk-kasus-kekerasan-seksual-padaanak-meningkat-tiap-tahun.

Bustamante, G. et al. (2019) 'Child Abuse \& Neglect " I have the right to feel safe ": Evaluation of a school-based child sexual abuse prevention program in Ecuador', Child Abuse \& Neglect. Elsevier, 91(November 2018), pp. 3140. doi: 10.1016/j.chiabu.2019.02.009.

Dasna, I. W., Laksana, D. N. L. and Sudhata, I. G. W. (2015) Desain dan Model Pembelajaran Inovatif dan Kreatif. Jakarta: Universitas Terbuka Press.

Haryana, D., Djaja, M. and Maznah, N. (2017) Melindungi Anak dari Kekerasan Seksual. pertama. Edited by A. Listyowati et al. Jakarta: Kementrian Pendidikan dan Kebudayaan. Available at: https://www.google.com/search?q= Judul+Seri+Pendidikan+Orang+Tua $\%$ $3 \mathrm{~A}+$ Melindungi + Anak + dari + Kekeras an+Seksual\&oq $=$ Judul + Seri + Pendidik an+Orang + Tua $\% 3 \mathrm{~A}+$ Melindungi $+\mathrm{An}$ $\mathrm{ak}+$ dari + Kekerasan + Seksual\&aqs $=\mathrm{chr}$ 
ome..69i57.882j0j4\&sourceid=chrome $\& \mathrm{ie}=\mathrm{UTF}-8$.

Indrayani, T. and Namira, N. (2020) 'Efektivitas Komik Edukasi terhadap Upaya Pencegahan Kekerasan pada Anak Sekolah Dasar Negeri Penggilingan 09 Pagi Jakarta Timur Tahun The Effectiveness of Educational Comics on The Prevention of Violence in Elementary School Children', Majalah Sainstekes, 7(1), pp. 51-57.

Justicia, R. (2016) 'Program Underwear Rules Untuk Mencegah', Jurnal Pendidikan Usia Dini, 9(2), pp. 217-232.

Kemenkumham RI (2014) Undang-Undang Republik Indonesia No 35 tahun 2014 Tentang Perubahan Atas UndangUndang Nomor 23 Tahun 2002 Tentang Perlindungan Anak. Republik Indonesia.

Ligina, N. L., Mardhiyah, A. and Nurhidayah, I. (2018) 'Peran Orang Tua Dalam Pencegahan Kekerasan Seksual Pada Anak Sekolah dasar di Kota Bandung', ejournal UMM, 9(2), pp. 109-118. Available at: http://ejournal.umm. ac.id/index.php/keperawatan/article/ view/5454\%0A.
Müller, A. R., Röder, M. and Fingerle, M. (2014) 'Child sexual abuse prevention goes online: Introducing "cool and Safe" and its effects', Computers and Education, 78, pp. 60-65. doi: 10.1016/j.compedu.2014.04.023.

Navaei, M., Akbari-kamrani, M. and Esmaelzadeh-saeieh, S. (2018) 'Effect of Group Counseling on Parents ' Communication Practice in Preventing Sexual Abuse of Children Aged 2-6 Years : A Randomized Controlled Clinical Trial O riginal A rticle', 6(4), pp. 285-292.

Oktarina, N. D. and Liyanovitasari, L. (2019) 'Media Cerita Bergambar Tentang Pengenalan Seks Dini Meningkatkan Pengetahuan Anak Usia Dini', JURNAL KESEHATAN PERINTIS (Perintis's Health Journal), 6(2), pp. 110-115. doi: 10.33653/jkp.v6i2.296.

Perry, S. E. et al. (2014) Maternal Child Nursing Care. Edited by K. Cashion and Alden. St Louis Missouri: Elsevier.

Russell, D., Higgins, D. and Posso, A. (2020) 'Preventing child sexual abuse: A systematic review of interventions and their efficacy in developing countries', 
Child Abuse and Neglect. Elsevier, 102(January), p. 104395. doi: 10.1016/j. chiabu.2020.104395.

Setyawan, D. (2014) Setiap Bulan 129 Anak Jadi Korban Kekerasan Seksual. Available at: http:/www.kpai.go.id/ berita/kpai-setiap-bulan-129-anakjadi-korban-kekerasan-seksual.

Sulistyowati, A., Matulessy, A. and Pratikto, H. (2018) 'Psikoedukasi Seks: Meningkatkan pengetahuan untuk Mencegah Pelecehan Seksual pada Anak Prasekolah', Jurnal Ilmiah PsikologiTerapan,6(14),pp.63-65.doi: 10.15900/j.cnki.zylf1995.2018.02.001.

Tunc, G. C. et al. (2018) 'Determining the Appropriateness of the "What If " Situations Test ( WIST) with Turkish Pre-Schoolers Determining the Appropriateness of the "What If" Situations Test ( WIST ) with Turkish Pre-Schoolers', Journal of Child Sexual Abuse. Routledge, 0(0), pp. 1-13. doi: 10.1080/10538712.2018.1425947.
Tutty, L. M. et al. (2019) 'The "Who Do You Tell ?" тм Child Sexual Abuse Education Program: Eight Years of Monitoring The "Who Do You Tell ? " тм Child Sexual Abuse Education Program : Eight Years of Monitoring', Journal of Child Sexual Abuse. Routledge, 0(0), pp. 1-20. doi: 10.1080/10538712.2019.1663969.

Utami, D. R. R. B. and Fatmawati, S. (2016) 'Pengalaman Guru Mengajarkan Pencegahan Kekerasan Seksual pada Anak Usia Prasekolah', Jurnal Ilmu dan Teknologi Kesehatan, 4(1), pp. $1-16$.

Utami, D. R. R. B. and Susilowati, T. (2018) 'Program “Aku Mandiri” Sebagai Upaya Pencegahan Kekerasan Seksual Pada Anak Usia Pra Sekolah', Gaster, 16 (2), p. 127. doi: 10.30787/gaster. v16i2.298.

Yamira, H. (2014) Right from the start. Jakarta: Kompas Gramedia. 